\title{
Antimicrobial activity of a Red Sea soft coral, Parerythropodium fulvum fulvum: reproductive and developmental considerations
}

\author{
Dovi Kelman ${ }^{1, *}$, Ariel Kushmaro ${ }^{1,2}$, Yossi Loya ${ }^{1,2}$, Yoel Kashman ${ }^{3}$, \\ Yehuda Benayahu ${ }^{1}$
}

${ }^{1}$ Department of Zoology, George S. Wise Faculty of Life Sciences, ${ }^{2}$ The Porter Super-Center for Ecological and Environmental Studies, and ${ }^{3}$ School of Chemistry, Tel Aviv University, Ramat Aviv, Tel Aviv 69978, Israel

\begin{abstract}
Living corals are frequently colonized by bacteria that may be pathogenic. One way they are able to combat microbial attack is by chemical defense. This is especially critical for the early developmental stages of the coral. Extracts from various reproductive and developmental stages of the Red Sea soft coral Parerythropodium fulvum fulvum exhibited antimicrobial activity against several cooccurring and potentially pathogenic marine bacteria. High activity was found particularly against Vibrio sp. (strain P-1), isolated from a necrotic coral tissue. However, no antimicrobial activity was observed against the coral-associated bacterial strains isolated from the coral tissue and its mucoid surface. The minimum inhibitory concentration of the coral crude extract against this Vibrio sp. was $1.25 \mathrm{mg} \mathrm{ml}^{-1}$ Bioassay-guided fractionation of the coral extract indicated that the antimicrobial activity was due to the presence of a range of secondary compounds of different polarities, which were also present in the tissue in trace amounts. The antimicrobial activity was present in all reproductive and developmental stages of the coral against the sensitive bacteria. This study provides the first comprehensive evidence for antimicrobial activity in coral larvae against co-occurring marine bacteria. It is concluded that antimicrobial activity detected in the extracts of $P$. f. fulvum is specific rather than broad spectrum. This specificity may be important in order to enable certain bacteria to live in close association with their coral host.
\end{abstract}

KEY WORDS: Antimicrobial activity - Chemical defense $\cdot$ Coral development - Octocorallia Marine bacteria Red Sea

\section{INTRODUCTION}

Soft corals (Octocorallia, Alcyonacea) are a highly diverse group of marine organisms which are known to contain a rich variety of secondary metabolites. It has been found that these compounds serve several biological and ecological roles (see reviews by Sammarco \& Coll 1988, 1992, Coll 1992, Paul 1992). They may act as defense against predators, as demonstrated by Van Alstyne et al. (1994) for extracts of 3 Sinularia species, as well as being involved in interspecific competition for space (e.g. Sammarco et al. 1983, La Barre et al. $1986)$ and in prevention of fouling on the coral tissue

•E-mail: kelmand@ccsg.tau.ac.il
(Coll et al. 1987). In addition, a range of secondary metabolites play an important role in reproduction of alcyonaceans. Certain diterpenes, such as thunbergol and epi-thunbergol, are present exclusively in the eggs of Lobophytum compactum and L. Crassum, but do not appear to be effective antifeedants against reef fish, nor do they possess effective antibacterial properties (Bowden et al. 1985, Sammarco \& Coll 1992). More recent evidence suggests that (-)-epi-thunbergol acts as a sperm chemo-attractant in the eggs of $L$. crassum (Coll et al. 1995).

Antimicrobial activity of secondary metabolites has been reported extensively for various groups of marine organisms, such as sponges (Burkholder \& Ruetzler 1969, Bergquist \& Bedford 1978, Amade et al. 1982, 
McCaffrey \& Endean 1985, Amade et al. 1987, Becerro et al. 1994), bryozoans (Walls et al. 1993), ascidians (Wahl et al. 1994), scleractinian corals (Koh 1997), gorgonian octocorals (Burkholder \& Burkholder 1958, Kim 1994, Jensen et al. 1996) and alcyonacean soft corals, as found in the Antarctic species Alcyonium paessler and Gersemia antarctica (Slattery et al. 1995). Most of the above-mentioned studies examined the activity of secondary metabolites against biomedically relevant microbes, such as human pathogens or marine bacteria, that have no ecological relevance to the studied organism. A few of the recent reports have looked at the activity of secondary metabolites against ecologically relevant bacteria in order to elucidate their function in the mediation of marine sessile invertebrate interactions with bacteria (Becerro et al. 1994, Wahl et al. 1994, Slattery et al. 1995, Jensen et al. 1996). In these studies, the antimicrobial activity assays were conducted on bacteria isolated from the natural environment of the organism being studied.

Bacteria are known to be abundant and active around corals and in their surface microlayer (Mitchell \& Chet 1975, Ducklow \& Mitchell 1979a, Ritchie \& Smith 1995). However, little information exists on the structure, composition and maintenance of such bacterial communities. The surface of living corals is covered by a muco-polysaccharide material (Ducklow \& Mitchell 1979a). This provides a matrix for bacterial colonization, allowing the establishment of a normal bacterial community', which may be characteristic of a particular coral species (Mitchell \& Chet 1975, Ducklow \& Mitchell 1979a, Rublee et al. 1980, Segel \& Ducklow 1982, Ritchie et al. 1994). Some of these bacteria can be pathogenic to corals, and may initiate diseases such as black band disease (Antonius 1985, Edmunds 1991) or tissue necrosis (Hodgson 1990). In addition, it has been recently demonstrated that bleaching of the Mediterranean scleractinian. coral Oculina patagonica is caused by bacterial infection, and that this infection is temperature dependent (Kushmaro et al. 1996, 1997). Since microorganisms are ubiquitous in the marine environment, corals need to resist microbial colonization and invasion of potential pathogens, in order to prevent possible harmful effects.

Parerythropodium fulvum fulvum (Forskal 1775) is an encrusting soft coral commonly found between 3 and $40 \mathrm{~m}$ depth at the coral reefs of the Gulf of Eilat, Red Sea (Benayahu \& Loya 1977). This species is gonochoric and reproduces annually during the summer (end of June to the beginning of August) by a unique mode of reproduction, which involves the surface brooding of embryos in a layer of mucus (Benayahu \& Loya 1983). The development of these embryos to a mature planula stage lasts $6 \mathrm{~d}$, at which time they detach from the colony surface and sink to the reef bottom. It has been suggested that surface brooding provides protection for the embryos during their development. As in many soft corals, P. f. fulvum contains a rich assemblage of secondary metabolites (Green et al. 1992). These metabolites are comprised mainly of sesquiterpenes, such as the volatile dye fulfulvene which gives the living colony its yellow color. The functions of these metabolites are still unknown.

In the current study we tested the activity of extracts from different reproductive and developmental stages of Parerythropodium fulvum fulvum, in order to determine whether they provide protection against ecologically relevant and co-occurring bacteria.

\section{MATERIALS AND METHODS}

Collection. Samples from different reproductive and developmental stages of Parerythropodium fulvum fulvum were collected using SCUBA from the reef across from the Marine Biological Laboratory of Eilat (northern Red Sea) at depths of 5 to $20 \mathrm{~m}$. Samples were collected during the breeding season of July to August 1995. One male and one female colony ( 1 and $3 \mathrm{~g}$ dry wt respectively) were collected for extraction since many of the colonies at our study site are being monitored in a long-term ecological study. The sex of the colonies was determined underwater by tearing a piece of coral tissue, and thus exposing the eggs or sperm sacs. Brooded embryos with mucus were collected daily from the surface of 3 to 5 different female colonies on consecutive dates throughout their $6 \mathrm{~d}$ developmental period, using a $50 \mathrm{ml}$ syringe. In the laboratory, some of the embryos obtained from a single colony were washed from mucus material twice with filtered seawater. After the breeding season, an additional colony with no gonads $(\sim 6 \mathrm{~g}$ dry wt) was collected in October 1996. All the above samples were used for the antimicrobial testing, and another colony with no gonads (17 $\mathrm{g}$ dry weight) was collected in May 1997 to be used for the bioassay-guided fractionation. All samples were frozen at $-20^{\circ} \mathrm{C}$ and transported to Tel Aviv for further analysis.

Samples for bacterial isolation were collected during April 1997 from the same location. Tissue samples ( $1 \times$ $1 \mathrm{~cm}$ in area, $\mathrm{n}=3$ ) of Parerythropodium fulvum fulrum were selected from colonies with no epiphytic algae and transferred to $50 \mathrm{ml}$ tubes with sterile seawater. Seawater samples $(\mathrm{n}=3)$ were collected in situ by filling $50 \mathrm{ml}$ sterile tubes near the coral colony. Reef substrate samples $(n=3)$ were scraped adjacent to $P$. $f$. fulvum colonies, and placed in similar tubes. Mucus samples were collected in the laboratory from 3 colonies, by placing them onto funnels and accumulat- 
ing the dripped mucus in $50 \mathrm{ml}$ sterile tubes kept on ice. Samples of necrotic tissue $(2 \times 1 \mathrm{~cm}$ in area, $\mathrm{n}=4)$ were also collected from degraded colonies found on the reef, and placed in tubes with sterile seawater. All samples were kept at $4^{\circ} \mathrm{C}$ and transferred to Tel Aviv for bacterial isolation.

Bacterial isolation and characterization. The tissue and reef substrate samples were ground and suspended in sterile seawater. $10 \mu \mathrm{l}$ of each of the bacterial isolation samples were diluted in sterile seawater, streaked onto Marine Agar $18 \mathrm{~g}$ Difco Marine Broth (MB), $9 \mathrm{~g} \mathrm{NaCl}$ and $18 \mathrm{~g}$ Difco Bacto Agar, per liter of deionized water], and incubated at $25^{\circ} \mathrm{C}$, corresponding to the ambient seawater temperature, for $3 \mathrm{~d}$. The dominant colony types were restreaked on Marine Agar to obtain pure cultures

The bacterial strains were routinely cultivated on Marine Agar or $\mathrm{MB}$ at $25^{\circ} \mathrm{C}$. Gram reaction and cell morphology were determined microscopically. Biochemical tests (indole production, nitrate from nitrite, acidification of glucose, arginine dihydrolyase, oxidase, esculine hydrolysis, gelatinase and $\beta$-galactosidase utilization, and utilization of glucose, arabinose, mannose, mannitol, maltose, gluconate, caprate, adipate, malate, citrate, phenyl-acetate, galactose, Nacetyl-glucosamine) were performed by api-20NE (micromethod tests for the identification of Gram-negative bacteria; bioMérieux sa, Marcy-l'Etoile, France). The standard api-20NE method was used, with the media being adjusted to $3 \% \mathrm{NaCl}$

Sensitivity to antibiotics (10 $\mu \mathrm{g}$ ampicillin, $15 \mu \mathrm{g}$ erythromycin, $10 \mu \mathrm{g}$ penicillin-G, $30 \mu \mathrm{g}$ tetracycline, $30 \mu \mathrm{g}$ kanamycin and $10 \mu \mathrm{g}$ streptomycin, each applied to a paper disc) was determined after incubation for $24 \mathrm{~h}$ at $25^{\circ} \mathrm{C}$ on Marine Agar.

Extraction. The samples from different reproductive and developmental stages of Parerythropodium fulvum fulvum (see above: 'Collection') were extracted in $20 \%$ methanol in dichloromethane. They were first sonicated for $5 \mathrm{~min}$, and then extracted for $24 \mathrm{~h}$ at room temperature. The organic extracts were separated from the water phase using a $20 \mathrm{ml}$ separation funnel, filtered, and then the solvent was removed by rotary evaporator under vacuum at 10 to $15^{\circ} \mathrm{C}$ bath temperature. This procedure was employed in order to avoid evaporation of volatile compounds known for $P$. $f$. fulvum (see Green et al. 1992). The dried extracts were weighed and kept at $-20^{\circ} \mathrm{C}$ prior to the antimicrobial assays. The natural extract concentration of colonies of P. f. fulvum was determined prior to the antimicrobial assays as described by Kelman (1998), using a standard volumetric method. By this method, 3 frozen colonies were placed into a cylinder with $50 \mathrm{ml}$ of the extract solution (see above), and the volume displaced was recorded. These colonies were extracted as indi- cated and the crude extracts were weighed. This resulted in a mean natural concentration of $0.84 \pm 0.09$ mg per 30 l $(n=3)$ that was used in the antimicrobial assays

In order to test the possible antimicrobial activity of extracts of the coral bacterial isolates, $10 \mathrm{ml}$ of overnight cultures (approximately $5 \times 10^{8}$ cells $\mathrm{ml}^{-1}$ estimated by viable counts) were concentrated by centrifugation [9000 rpm $(9680 \times g)$ for $20 \mathrm{~min}]$. The pellets were then extracted as described above.

Antimicrobial assay. The standard agar disc-diffusion method (Barry 1980) was performed to test for antibacterial activity of the coral reproductive and developmental stages and bacterial extracts. Inocula of overnight culture (approximately $10^{7}$ cells) of each bacterial strain were streaked onto the surface of a Marine Agar plate. The inocula were spread with a sterile glass rod to provide a uniform film of the test strain. Dictated by the availability of the extracts, 3 subsamples for most extracts were tested by pipetting $30 \mu \mathrm{l}$ of natural extract concentration, containing $0.84 \mathrm{mg}$ dissolved in ethanol, onto $6 \mathrm{~mm}$ circular sterile paper discs (Whatman), allowing the solvent to evaporate, and placing the discs onto the surface of the inoculated agar. The test and solvent control discs were then incubated for 24 h at $25^{\circ} \mathrm{C}$.

Areas of inhibited bacterial growth were observed as clear halos (zones) around the discs. Antibacterial activity was measured as the diameter of the zone of inhibition, minus the paper disc diameter. Antimicrobial activities were calculated for each extract as the mean zone of inhibition of repeated activity tests.

Minimum inhibitory concentration (MIC) was measured by determining the smallest amount of extract needed to inhibit the growth of the test bacterium (strain P-1). A series of tubes containing $1 \mathrm{ml}$ of $\mathrm{MB}$ medium was prepared, and different extract concentrations (ranging from 0.15 to $60 \mathrm{mg} \mathrm{ml}^{-1}$ ) were added to each tube. After overnight incubation at $25^{\circ} \mathrm{C}$, the tubes in which growth did not occur were noted. The type of action of the antimicrobial agents was determined by adding $28 \mathrm{mg} \mathrm{ml}^{-1}$ (mean natural extract concentration) to a logarithmic culture of bacterial strain P-1. Viable counts were then performed on Marine Agar over time, and turbidity was measured using a Klett Summerson photometer

Bioassay-guided fractionation. Bioassay-guided fractionation was performed on a colony of Parerythropodium fulvum fulvum with no gonads that was extracted as outlined above in order to partially isolate and characterize the antimicrobial agent/s of the coral. Initial fractionation of the crude organic extract was accomplished by solvent partitioning using petrol ether (PE), dichloromethane, and n-butanol as solvent systems against aq. methanol $\left(10\right.$ to $\left.20 \% \mathrm{H}_{2} \mathrm{O}\right)$. The 
fractions were evaporated to dryness under reduced pressure using a rotary evaporator, and assayed for antimicrobial activity against bacterial strain P-1. For further purification we used the fraction that exhibited appreciable activity and contained the largest amount of material. This fraction was loaded on a LH-20 Sephadex column using a 2:1:1 PE:chloroform: methanol solvent system. The fractions were assayed for antimicrobial activity and the most active fraction used for further purification. This fraction was partitioned by silica vacuum liquid chromatography (VLC), eluting with solvents of increasing polarity (from 100\% PE to $100 \%$ ethyl-acetate). A similar VLC column was then applied to one of the active fractions that contained of enough material. The resulting fractions were then assayed for antimicrobial activity. The bioassayguided fractionation was stopped before any active pure compounds were obtained due to the lack of sufficient material for further fractionation. The composition of any fraction was analyzed using thin-layer chromatography (TLC) and ${ }^{1} \mathrm{H}$-NMR ( ${ }^{1} \mathrm{H}$-nuclear magnetic resonance) spectroscopy.

Statistical analysis. The statistical analyses of the data were performed in 2 stages. First, we conducted a $G$-test for analyses of frequencies (Sokal and Rohlf 1995), comparing the proportion of extracts from different samples and their subsamples that did or did not exhibit antimicrobial activity, defined as zone of inhibition around the discs greater than zero. These tests were followed by a $2 \times 2$ test of independence, comparing the pooled activity frequencies of the coral-associated bacteria with the other strains tested. Second, a series of single-classification ANOVA tests were performed on each bacterial strain against the extracts from the different reproductive and developmental stages, and on each extract type against the different bacterial strains tested. These tests were followed by post hoc compar-

Table 1. Description of isolated bacteria used in the antimicrobial assays. Bacterial species were identified by api-20NE method

\begin{tabular}{|llcll|}
\hline $\begin{array}{l}\text { Bacterial } \\
\text { strain }\end{array}$ & Source & $\begin{array}{c}\text { Gram } \\
\text { reaction }\end{array}$ & $\begin{array}{c}\text { Bacterial } \\
\text { shape }\end{array}$ & Species \\
\hline D-1 & Non-gravid coral & - & Rod & Pseudomonas sp. \\
M-1 & Mucus & - & Rod & Pseudomonas sp. \\
M-2 & Mucus & - & Rod & Vibrio sp. \\
M-3 & Mucus & - & Rod & Pseudomonas vesicularis \\
S-1. & Reef substrate & - & Rod & Pseudomonas sp. \\
S-2 & Reef substrate & - & Coccobacilli & Unidentified \\
S-3 & Reef substrate & - & Rod & Unidentified \\
P-1 & Degradated coral & - & Rod & Vibriosp. \\
P-2 & Degradated coral & - & Rod & Unidentified \\
SW-1 & Sea water & - & Rod & Pseudomonas sp. \\
SW-2 & Sea water & - & Coccobacilli & Chryseomonas sp. \\
SW-3 & Sea water & + & Cocci & Unidentified \\
& & & & \\
\hline
\end{tabular}

isons in order to determine which bacterial strain or extract type contributed to the overall significance. Because the antimicrobial activity data contained a large number of zeros (see below) and were not normally distributed, we included only those bacterial strains which exhibited appreciable antimicrobial activity in the second part of the analysis. These partial data sets met the requirements for parametric analyses.

\section{RESULTS}

\section{Bacterial isolation and characterization}

Twelve strains of bacteria were isolated from samples of Parerythropodium fulvum fulvum with no gonads, from coral mucus, degraded coral, reef substrate and from seawater adjacent to the colonies. Their characteristics and partial identification are summarized in Table 1. All of them were Gram-negative bacteria, except for strain SW-3 which was Gram-positive. These strains exhibited variable sensitivity to different commercial antibiotics (Table 2), demonstrating that they were different bacterial strains. The bacteria that were isolated from the coral and mucus samples (strains D-1, M-1, M-2, and M-3) generally exhibited more resistance to commercial antibiotics, especially the $\beta$-lactam antibiotics penicillin and ampicillin, than the other test bacteria.

\section{Antimicrobial assays}

Six types of organic extracts derived from a colony with no gonads, male and female colonies with gonads, 1 to $2 \mathrm{~d}$ old embryos with mucus, 3 to $6 \mathrm{~d}$ old embryos with mucus and 3 to 6 d old embryos without mucus, representing different reproductive and developmental stages of Parerythropodium fulvum fulvum, were tested for antimicrobial activity against the 12 strains of marine bacteria at concentrations found in the living coral. While no significant antimicrobial activity was exhibited against the coral-associated bacterial strains D-1, M-1, M-2 and M-3 (Table 3), an appreciable but variable antimicrobial activity was exhibited against 5 of the remaining strains. Among the 248 tests analyzed, $122(49 \%)$ resulted in antimicrobial activity, $98 \%$ of which was exhibited against 4 bacterial strains (S-1, P-1, SW-1, SW-2). Strain SW-3 was not included in any of the 
Table 2. Sensitivity of the isolated test bacteria to commercial antibiotics. The applied concentrations are noted in parentheses Sensitivity is expressed as inhibition zones (diameter in $\mathrm{mm}$ ) around each antibiotic disc, R: resistance to antibiotics. nd: no data

\begin{tabular}{|c|c|c|c|c|c|c|}
\hline $\begin{array}{l}\text { Bacterial } \\
\text { strain }\end{array}$ & $\begin{array}{c}\text { Kanamycin } \\
(30 \mu \mathrm{g})\end{array}$ & $\begin{array}{l}\text { Penicillin-G } \\
\quad(10 \mu \mathrm{g})\end{array}$ & $\begin{array}{l}\text { Ampicillin } \\
(10 \mu \mathrm{g})\end{array}$ & $\begin{array}{l}\text { Streptomycin } \\
\quad(10 \mu \mathrm{g})\end{array}$ & $\begin{array}{l}\text { Erythromycin } \\
\qquad(15 \mu \mathrm{g})\end{array}$ & $\begin{array}{c}\text { Tetracycline } \\
(30 \mu \mathrm{g})\end{array}$ \\
\hline D-1 & $\mathrm{R}$ & $\mathrm{R}$ & $\mathrm{R}$ & 4 & 16 & 10 \\
\hline$M-1$ & 9 & $R$ & 19 & 8 & 18 & 3 \\
\hline M-2 & 13 & $R$ & $\mathrm{R}$ & 9 & 10 & 3 \\
\hline$M-3$ & 10 & $\mathrm{R}$ & 10 & 8 & 14 & 4 \\
\hline S-1 & 3 & 20 & 25 & $\mathrm{R}$ & 20 & 14 \\
\hline S-2 & 8 & $\mathrm{R}$ & $\mathrm{R}$ & 4 & nd & 4 \\
\hline S-3 & 8 & 7 & 13 & 5 & 6 & 6 \\
\hline P-1 & 9 & 10 & 14 & 4 & 10 & 10 \\
\hline P-2 & 25 & 20 & 25 & 20 & 10 & 6 \\
\hline SW-1 & 25 & 25 & 25 & 25 & 25 & 25 \\
\hline SW-2 & 6 & 28 & nd & 11 & 34 & 20 \\
\hline SW-3 & 14 & 25 & 25 & 19 & 25 & 16 \\
\hline
\end{tabular}

Table 3. Parerythropodium fulvum fulvum. Antimicrobial activity of extracts from various reproductive and developmental stages described as inhibition zone (mean diameter in $\mathrm{mm} \pm \mathrm{SD}$ ) against the isolated bacterial test strains

\begin{tabular}{|c|c|c|c|c|c|c|}
\hline $\begin{array}{l}\text { Bacterial } \\
\text { strain }\end{array}$ & $\begin{array}{l}\text { Non-gravid } \\
\text { coral }\end{array}$ & $\begin{array}{c}\text { Gonad-bearing } \\
\text { female }\end{array}$ & $\begin{array}{c}\text { Gonad-bearing } \\
\text { male }\end{array}$ & $\begin{array}{l}1-2 \text { d old } \\
\text { embryas } \\
+ \text { mucus }\end{array}$ & $\begin{array}{l}\text { 3-6 d old } \\
\text { embryos } \\
+ \text { mucus }\end{array}$ & $\begin{array}{l}3-6 \text { d old } \\
\text { embryos }\end{array}$ \\
\hline$D-1$ & 0 & 0 & 0 & 0 & 0 & 0 \\
\hline$M i-\hat{I}$ & $0.5 \pm 0.41$ & $0.3 \pm 0.47$ & 0 & 0 & 0 & 0 \\
\hline$M-2$ & 0 & 0 & 0 & 0 & 0 & 0 \\
\hline M-3 & 0 & 0 & 0 & 0 & 0 & 0 \\
\hline S-1 & $5.9 \pm 0.45$ & $6.6 \pm 0.45$ & $5.7 \pm 1.25$ & $3.9 \pm 1.24$ & $2.7 \pm 1.21$ & $3.8 \pm 0.40$ \\
\hline$S-2$ & 0 & 0 & 0 & 0 & 0 & 0 \\
\hline S-3 & 0 & 0 & 0 & 0 & 0 & 0 \\
\hline P-1 & $5.2 \pm 1.95$ & $6.1 \pm 1.24$ & $4.2 \pm 2.71$ & $3.5 \pm 0.76$ & $0.8 \pm 0.80$ & $4.7 \pm 0.47$ \\
\hline P-2 & 0 & 0 & 0 & 0 & 0 & 0 \\
\hline SW-1 & $3.8 \pm 0.62$ & $2.7 \pm 0.75$ & $2.5 \pm 0.50$ & $2.2 \pm 0.90$ & $0.8 \pm 0.62$ & $2 \pm 0$ \\
\hline$S W-2$ & $2.9 \pm 0.61$ & $2.7 \pm 1.11$ & $3.3 \pm 1.30$ & $1.5 \pm 0.87$ & $0.5 \pm 0.5$ & $1 \pm 0$ \\
\hline SW-3 & $2 \pm 0$ & $1 \pm 1.41$ & $1.3 \pm 1.25$ & $1 \pm 1.41$ & 0 & 0 \\
\hline
\end{tabular}

data analysis, even though the results for this strain are presented in Table 3, since it grew very poorly. Comparison of pooled activity frequencies of coral-associated bacterial strains (D-1, M-1, M-2, and M-3) with the pooled activity frequencies of non-associated coral bacterial strains showed a significant difference ( $G$-test of independence, $\mathrm{p} \ll 0.001$ ).

The highly variable yet considerable activity of extracts from different reproductive and developmental stages against 4 of the 12 bacterial strain tested (S-1, P-1, SW-1, SW-2) was analyzed using a series of single-classification ANOVAs. These tests were performed on each of the 4 bacterial strains against the different extracts, and on each extract type against the different sensitive bacteria. All tests resulted in high significance $(p<0.001)$. Post hoc comparisons revealed that the activities were variable among the different sensitive bacteria and among the extract types.
Vibrio sp. strain P-1 exhibited high sensitivity against the coral extracts (Table 3 ). Because it was isolated from necrotic tissue and thus was a potentially pathogenic marine bacterium, we used it for further antimicrobial analyses. The results revealed that the MIC of the crude extract of coral with no gonads against Vibrio sp. strain P-1 was $1.25 \mathrm{mg} \mathrm{ml}^{-1}$ of growth medium. Moreover, the overall mechanism of action of antimicrobial agent/s of the coral crude extract was bacteriocidal. This was determined by the fact that viable counts decreased over time, while the turbidity of the test culture remained constant.

In order to test the possible contribution of the coralassociated bacteria to the overall antimicrobial activity, the bacterial strains D-1, M-1, M-2 and M-3 were extracted and assayed against Vibrio sp. strain P-1. These assays resulted in no growth inhibition of the test bacterium. 

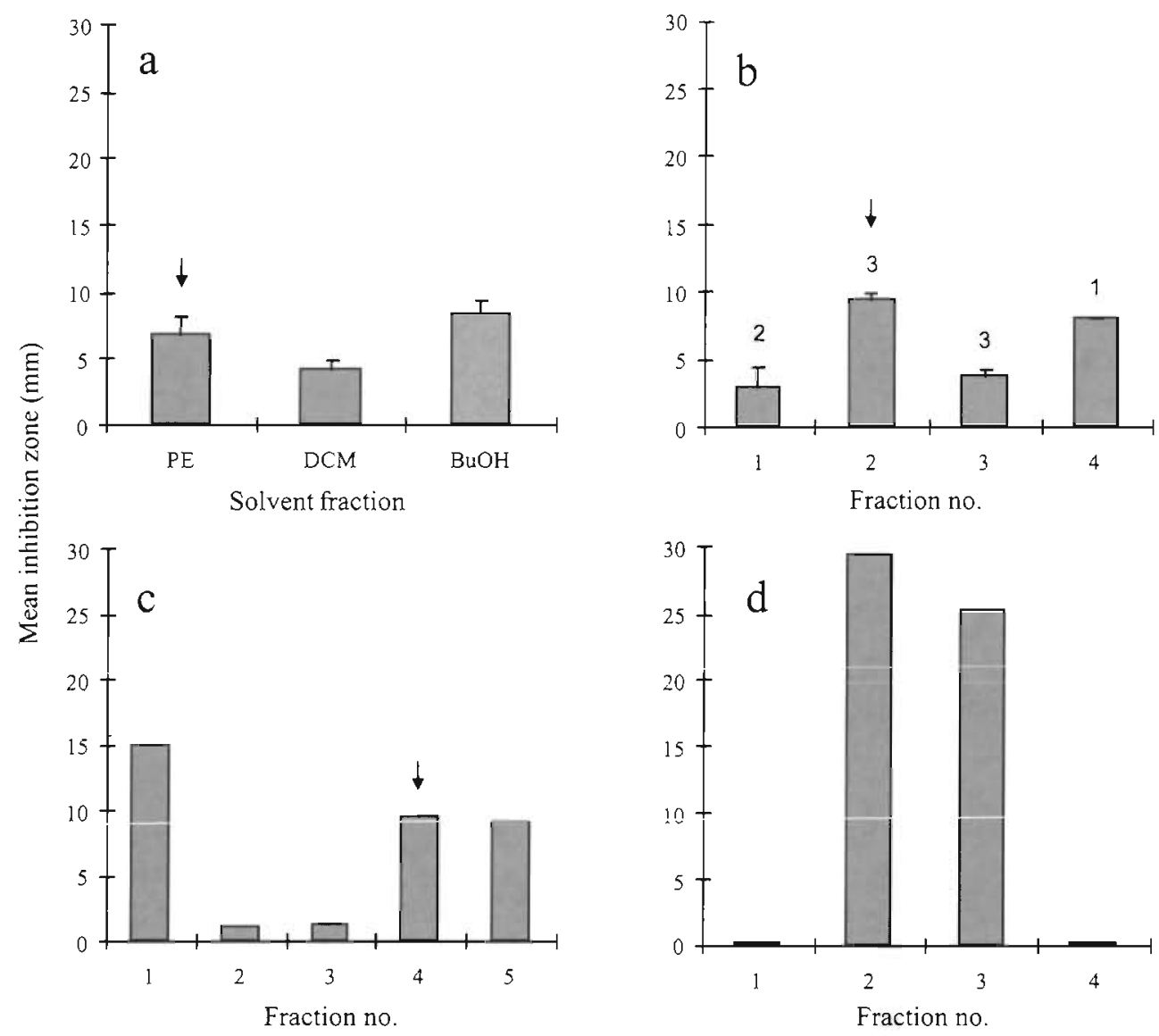

Fig. 1. Parerythropodium fulvum fulvum. Bioassay-guided fractionation of antimicroblal activity of $P$. f. fu/vum extract described as inhibition zone (mean diameter + SD) against Vibrio sp. strain P-1. Arrows indicate the fraction used for the following fractionation. (a) Results of solvent partitioning fractionation ( $n=3$ in each bar); (b) results of LH-20 Sephadex column fractionation ( $n$ indicated above each bar); (c) results of the first silica VLC: (vacuum liquid chromatography) fractionation ( $\mathrm{n}=1$ in each bar); and (d) results of the second silica VLC fractionation $(\mathrm{n}=1$ in each bar). PE: petrol ether; DCM: dichloromethane; BuOH: $n$-butanol

\section{Bioassay-guided fractionation}

Initial fractionation of the crude extract of the colony with no gonads by solvent partitioning yielded 3 fractions, which were active against Vibrio sp. strain P-1 (Fig. 1a). The highest activity was present in the $n$ butariol and PE soluble fractions, with mean inhibition zones of $8.3 \pm 1.15(\mathrm{n}=3)$ and $6.67 \pm 1.53(\mathrm{n}=3) \mathrm{mm}$ respectively. Since most of the material was present in the PE soluble fraction, it was used for further purification, and its fractionation with LH-20 Sephadex column yielded 4 fractions. The highest activity was present mainly in fractions 2 and 4 with mean zone of inhibition of $9.3 \pm 0.57(n=3)$ and $8(n=1)$ mm respectively (Fig. 1b). Fraction 2, which was the most active, was loaded on a silica VLC column and yielded 5 fractions. Antimicrobial activity was present mainly in fractions 1, 4 and 5 (Fig. 1c). Since fraction 4 demon- strated appreciable activity and contained enough material, it was loaded on another silica VLC column, and yielded another 4 fractions, of which only fractions 2 and 3 demonstrated high antimicrobial activity (Fig. 1d). ${ }^{1} \mathrm{H}$-NMR analyses indicated that the major compound(s) in one of the active fractions (Fig. 1c, fraction 1) seemed to be an isoprenoid. This compound(s) contained a variety of functional groups, such as double bonds, conjugated double bonds, hydroxyl groups and most likely also an epoxide(s). The small amount of impurities which could not be removed might have been responsible for the antimicrobial activity. TLC and ${ }^{1} \mathrm{H}-\mathrm{NMR}$ analysis on fractions 2 and 3 of the second VLC fractionation. (Fig. 1d) revealed that they were even more complex and that they were composed of several compounds. No additional bioassayguided fractionation was conducted due to lack of sufficient material and instability. 


\section{DISCUSSION}

Extracts from different reproductive and developmental stages of Parerythropodium fulvum fulvum exhibited appreciable but variable antimicrobial activity against several co-occurring and potentially pathogenic marine bacteria isolated from the vicinity of the coral. However, no antimicrobial activity was observed against the coral-associated bacterial strains D-1, M-1, M-2 and M-3, isolated from the coral tissue and mucoid surface. Care was taken in this study to use bacteria that were either isolated from the coral or in its vicinity. The approach of using ecologically relevant bacteria as test strains, as opposed to terrestrial or marine bacteria which lack ecological relevance, has been discussed in several recent publications (Becerro et al. 1994, Slattery et al. 1995, Jensen et al. 1996). Furthermore, the antimicrobial assays in the present study were carried out at equivalent extract concentrations to those found in the living coral. The importance of using ecologically realistic extract concentrations was demonstrated by Jensen et al. (1996), who used a volumetric method on every coral sample in order to measure the natural extract concentration. Since in the current study we were interested in detecting activity differences among samples at different reproductive and developmental stages, a constant extract concentration was used. This was determined prior to the assay by calculating the mean natural concentration found in the coral. Thus, the obtained differences were due to changes in composition of the extract, rather than in the total concentration. These composition differences could be due to different concentrations of antimicrobial agents or different kinds of antimicrobial compounds present in the extract.

Several studies have demonstrated that a natural bacterial community is established in coral mucoid surfaces (Mitchell \& Chet 1975, Ducklow \& Mitchell 1979a, Rublee et al. 1980, Segel \& Ducklow 1982, Ritchie et al. 1994). These bacterial populations generally appear as 'good microbes', being a source of nutrition for the coral host (Sorokin 1978, Ducklow 1990). However, such bacteria may under certain conditions become pathogenic (Mitchell \& Chet 1975, Ducklow \& Mitchell 1979b, Kushmaro et al. 1997). Although broad spectrum antimicrobial activity was not detected in Parerythropodium fulvum fulvum, as shown in other corals (Jensen et al. 1996, Koh 1997), we distinguish the ecological difference between coral associated bacteria and other bacteria isolated from the environment of the coral. The data show that no activity was present against strains D-1, M-1, M-2 and M-3 (selected coral-associated bacterial strains), whereas appreciable activity was present against other isolated bacteria. Therefore, we conclude that the antimicrobial agents of $P$. f. fulvum are species specific rather than of a broad spectrum. Such specificity is probably important in maintaining the natural bacterial community of the coral host. In order for certain bacteria to live in close association with $P$. f. fulvum, they require the ability to resist specific antimicrobial agents produced by the coral. However, in view of the fact that $<1 \%$ of living marine bacteria is culturable (Bianchi \& Giuliano 1996), caution should be taken in drawing such a conclusion.

Certain symbiotic marine bacteria have been shown to be responsible for the production of secondary metabolites that were previously thought to be derived from their host (Elyakov et al. 1991, Mikki et al. 1996). These compounds in some cases were found to have anti-fungal properties, and thus protect their host from fungal attack (Gil-Turnes et al. 1989, Gil-Turnes \& Fenical 1992). We have shown that the coral associated bacterial strains did not contribute to the overall coral antimicrobial activity. Nevertheless, it is still possible that the antimicrobial agents could have derived from other microbes that have not been isolated yet, or that they were not induced or extracted using the methods employed here.

The MIC of the coral crude extract against the Vibrio $\mathrm{sp}$. strain $\mathrm{P}-1$ was $1.25 \mathrm{mg} \mathrm{ml}^{-1}$, while the mean natural extract concentration of Parerythropodium fulvum fulvum was $28 \mathrm{mg} \mathrm{ml}^{-1}$. This result explains the high antimicrobial activity observed in the disc-diffusion method (Table 3). The simulation of natural concentration on a volumetric basis assumes, as described by Kim (1994), that the extracts are equally distributed throughout the volume of the coral. However, it may be possible that a higher concentration of extract, or even a higher concentration of antimicrobial compounds, accumulates at the surface of the coral, thus preventing bacterial or other harmful attacks. If this is the case, higher activity would possibly be detected if the natural concentration of an extract from the surface tissue was applied. Additional studies are needed in order to determine if a differential antimicrobial activity does indeed exist throughout the volume of corals, or of other sessile marine organisms.

Bioassay-guided fractionation of the extract of Parerythropodium fulvum fulvum with no gonads indicated that its antimicrobial activity was due to the presence of a variety of secondary compounds of different polarities. Furthermore, these assays indicated that the antimicrobial agents were highly potent at low concentrations, and their presence in the extract was in trace amounts, which made it difficult to purify the active compounds. The fact that the coral-associated bacteria exhibited resistance, especially to $\beta$-lactam antibiotics 
(e.g. penicillin and ampicillin), raises the possibility that at least one of the antimicrobial compounds mimics the antibiotic activity of this class. Further work is still required in order to determine the nature of such compounds, and to show whether individual metabolites act in an additive or synergistic fashion towards potentially harmful bacteria.

Several investigators have discussed the relationship between antimicrobial activity and the ability of an extract to deter potential predators (Kim 1994, Jensen et al. 1996). Given the rich assemblage of ichthyodeterrent compounds reported in many octocorals (e.g. Sammarco et al. 1987, Harvell et al. 1988, Sammarco \& Coll 1988, 1992, Fenical \& Pawlik 1991, Coll 1992), it still remains unclear whether a relationship exists between the palatability of a given species to predators and its antimicrobial activity. However, the feeding deterrent compound in Sinularia polydactyla, pukalide, also acts as an antimicrobial agent against cooccurring bacteria in their eggs and larvae (M. Slattery pers. comm.). Furthermore, Parerythropodium fulvum fulvum extracts have demonstrated strong unpalatability to reef fish (Kelman 1998). In turn, these findings suggest that natural products of this coral play an important role in the overall protection against microorganisms or other harmful agents.

Fusetani et al. (1996) demonstrated antimicrobial activity in eggs of the stony coral Montipora digitata against terrestrial microbes. Our study provides the first comprehensive evidence for antimicrobial activity in coral embryos against co-occurring marine bacteria. Palatability experiments performed with the embryo extracts against reef fish have revealed an appreciable feeding deterrence (Kelman 1998). Hence, our results demonstrate that natural products present in developmental stages of Parerythropodium fulvum fulvum play an important role in the broad-spectrum protection against microorganisms and predators. Further studies are warranted in order to better understand the ecological role of marine natural products, especially those derived from various developmental stages, in the mediation of coral-microbe interactions.

Acknowledgements. We thank E. Rosenberg for his excellent guidance and suggestions throughout this study. We are grateful to $M$. Slattery and 3 anonymous reviewers for helpful comments that improved the manuscript We thank the staff of the Inter University Institute of Marine Biology at Eilat for their hospitality and facilities. We thank A. Rudi for the NMR work, D. Wool for statistical advice, and N. Paz and C. Shapiro for editorial assistance. This paper is part of a thesis presented as partial fulfillment of the M.Sc. dissertation submitted by D.K. to Tel Aviv University. This research was supported in part by a grant to Y.B. from the Israel Science Foundation.

\section{LITERATURE CITED}

Amade P, Charroin C, Baby C, Vacelet J (1987) Antimicrobial activities of marine sponges from the Mediterranean Sea. Mar Biol 94:271-275

Amade P, Pesando D, Chevolot L (1982) Antimicrobial activities of marine sponges from French Polynesia and Brittany. Mar Biol 70:223-228

Antonius A (1985) Black band disease infection experiments on hexacorals and octocorals. Proc 5th Int Coral Reef Congr, Tahiti 6:155-160

Barry AI (1980) Procedures and theoretical consideration for testing antimicrobial agents in agar media. In: Lorian $V$ (ed) Antibiotics in laboratory medicine. William \& Wilkin, Baltimore, MD, p $1-16$

Becerro MA, Lopez NI, Turon X, Uriz MJ (1994) Antimicrobial activity and surface bacterial film in marine sponges. J Exp Mar Biol Ecol 179:195-205

Benayahu Y, Loya Y (1977) Space partitioning by stony corals, soft corais and benthic algae on the coral reefs of the northern Gulf of Eilat (Red Sea). Helgol Wiss Meeresunters $30: 362-382$

Benayahu Y, Loya Y (1983) Surface brooding in the Red Sea soft coral Parerythropodium fulvum fulvum (Forskål, 1775). Biol Bull (Woods Hole) 165:353-369

Bergquist PR. Bedford JJ (1978) The incidence of antibacterlai activity in marine Demospongiae; systematic and geographic considerations. Mar Biol 46:216-221.

Bianchi A, Giuliano L (1996) Enumeration of viable bacteria in marne pelagic environment. Appl Environ Microbiol 62(1):174-177

Bowden B, Coll J, Tapiolas D, Willis R (1985) Some chemical aspects of spawning in alcyonacean corals. Proc 5th Int Coral Reef Congr, Tahiti 4:325-329

Burkholder PR, Burkholder LM (1958) Antimicrobial activity of horny corals. Science 127:1174-1175

Burkholder PR, Ruetzler K (1969) Antimicrobial activity of some marine sponges. Nature 222:983-984

Coll JC (1992) The chemistry and chemical ecology of octocorals (Coelenterata, Anthozod, Octocorallia). Chem Rev 92(4):613-631

Coll JC, Leone PA, Bowden BF, Carroll AR, Konig GM, Heaton A, de Nys R, Maida M, Alino PM, Willis RH, Babcock RC, Florian Z, Clayton MN, Miller RL, Alderslade PN (1995) Chemical aspects of mass spawning in corals. II. (-)Epi-thunbergol, the sperm attractant in the eggs of the soft coral Lobophyton crassum (Cnidaria: Octocorallia). Mar Biol 123:137-143

Coll JC, Price IR, Konig GM, Bowden BF (1987) Algal overgrowth of alcyonacean soft corals. Mar Biol 96:129-135

Ducklow WH (1990) The biomass, production and fate of bacteria in coral reefs. In: Dubinsky $Z$ (ed) Ecosystems of the world: coral reefs. Elsevier, New York, p 265-289

Ducklow WH, MitchelJ. R (1979a) Bacterial populations and adaptations in the mucus layers on living corals. Limnol Oceanogr 24:715-725

Ducklow WH, Mitchell R (1979b) Composition of mucus released by coral reef coelenterates. Limnol Oceanogr 24: $706-714$

Edmunds PJ (1991) Extent and effect of black band disease on a Caribbean reef. Coral Reefs 10:161-165

Elyakov GB, Kuznetsova T, Mikhailov VV, Maltsev II, Voinov VG, Fedoreyev SA (1991) Brominated diphenyl ethers from a marine bacterium associated with the sponge Dysidea sp. Experientia (Basel) 47:632-633

Fenical W. Pawlik JR (1991) Defensive properties of secondary metabolites from the Caribbean gorgonian coral, 
Erythropodium caribaeorum. Mar Ecol Prog Ser 75:1-8

Fusetani $V$, Toyoda T, Asai N, Matsunaga S, Maruyama T (1996) Montiporic acids A and B, cytotoxic and antimicrobial polyacetylene carboxylic acids from the eggs of the scleractinian coral Montipora digitata. J Nat Prod 59: 796-797

Gil-Turnes MS, Fenical W (1992) Embryos of Homarus americanus are protected by epibiotic bacteria. Biol Bull (Woods Hole) 182:105-108

Gil-Turnes MS, Hay ME, Fenical W (1989) Symbiotic marine bacteria chemically defend crustacean embryos from a pathogenic fungus. Science 246:116-118

Green D, Kashman Y, Benayahu Y (1992) Secondary metabolites of the yellow and gray morphs of the soft coral Parerythropodium fulvum fulvum: comparative aspects. I Nat Prod 55(9):1186-1196

Harvell CD, Fenical W, Greene CH (1988) Chemical and structural defenses of Caribbean gorgonians (Pseudopterogorgia spp.) I. Development of an in situ feeding assay. Mar Ecol Prog Ser 49:287-294

Hodgson G (1990) Tetracycline reduces sedimentation damage to corals. Mar Biol 104:493-496

Jensen PR, Harvell CD, Wirtz K, Fenical W (1996) Antimicrobial activity of extracts of Caribbean gorgonian corals. Mar Biol 125:411-419

Kelman D (1998) The chemical ecology of the soft coral Parerythropodium fulvum fulvum. MSc dissertation, Tel Aviv University

Kim K (1994) Antimicrobial activity in gorgonian corals (Coelenterata, Octocorallia). Coral Reefs 13:75-80

Koh EGL (1997) Do scleractinian corals engage in chemical wartare against microbes? J Chem Ecol 23(2):379-398

Kushmaro A. Loya Y. Fine M, Rosenberg E (1996) Bacterial infection and coral bleaching. Nature 380:396

Kushmaro A, Rosenberg E, Fine M, Loya Y (1997) Bleaching of the coral Oculina patagonica by Vibrio AK-1. Mar Ecol Prog Ser 147:159-165

La Barre SC, Coll JC, Sammarco PW (1986) Competitive strategies of soft corals (Coelenterata: Octocorallia) III. Spacing and aggressive interactions between alcyonaceans. Mar Ecol Prog Ser 28:147-156

McCaffrey EJ, Endean R (1985) Antimicrobial activity of tropical and subtropical sponges. Mar Biol 89:1-8

Mikki W, Otaki N, Yokoyama A, Kusumi T (1996) Possible origin of zeaxanthin in the marine sponge, Reniera japonica. Experientia (Basel) 52:93-96

Mitchell R, Chet I (1975) Bacterial attack of corals in polluted seawater. Microb Ecol 2:227-233

Paul VJ (1992) Ecological roles of marine natural products.

Editonal responsibility: Joseph Pawlik (Contributing Editor), Wilmington, North Carolina, USA
Cornell University Press, New York

Ritchie KB, Smith GW (1995) Carbon source utilization pattern of coral associated marine heterotrophs. J Mar Biotechol 3:105-107

Ritchie KB, Smith GW, Gerace DT (1994) Grouping of bacterial heterotrophs from scleractinian corals using metabolic potentials. Proc 26th Meet Assoc Mar Lab Caribbean, San Salvador, Bahamas: Bahamian Field Station, p 224-236

Rublee AP, Lasker RH, Gottfriend M, Roman RM (1980) Production and bacterial colonization of mucus from the soft coral Briarium asbestinum. Bull Mar Sci 30(4):888-893

Sammarco PW, Coll JC (1988) The chemical ecology of alcyonarian corals (Coelenterata: Octocorallia). In: Scheuer PJ (ed) Bioorganic marine chemistry, Vol 2. Springer-Verlag, Berlin, p. 87-116

Sammarco PW, Coll JC (1992) Chemical adaptations in the Octocorallia: evolutionary considerations. Mar Ecol Prog Ser 88:93-104

Sammarco PW, Coll JC, La Barre SC, Willis B (1983) Competitive strategies of soft corals (Coelenterata: Octocorallia). Allelopathic effects on selected scleractinian corals. Coral Reefs 1:173-178

Sammarco PW, La Barre S, Coll JC (1987) Defensive strategies of soft corals (Coelenterata: Octocorallia) of the Great Barrier Reef: III. The relationship between ichthyotoxicity and morphology. Oecologia 74:93-101

Segel AL, Ducklow WH (1982) A theoretical investigation into the influence of sublethal stresses on coral-bacterial ecosystem dynamics. Bull Mar Sci 32(4):919-935

Slattery M, McClintock JB, Heine JN (1995) Chemical defenses in Antarctic soft corals: evidence for antifouling compounds. J Exp Mar Biol Ecol 190:61-77

Sokal RR, Rohlf FJ (1995) Biometry. The principles and practice of statistics in biological research, 3rd edn. WH Freeman and $\mathrm{Co}$, New York

Sorokin YI (1978) Microbial production in the coral reef community. Arch Hydrobiol 83:281-323

Van Alstyne KL, Wylie CR, Paul VJ (1994) Antipredator defenses in tropical Pacific soft corals (Coelenterata: Alcyonacea) II. The relative importance of chemical and structural defenses in three species of Sinularia. J Exp Mar Biol ECol 178:17-34

Wahl M, Jensen PR, Fenical W (1994) Chemical control of bacterial epibiosis on ascidians. Mar Ecol Prog Ser 110: $45-57$

Walls JT, Ritz DA, Blackman AJ (1993) Fouling, surface bacteria and antibacterial agents of four bryozoan species found in Tasmania, Australia. J Exp Mar Biol Ecol 169 $1-13$

Submitted: December 8, 1997; Accepted: May 4, 1998

Proofs recelved from author(s): June 30, 1998 